\title{
LAW AND THE LEGISLATIVE PROCESS IN OCCUPIED GERMANY: II*
}

\author{
KARL. LOEWENSTEINं \\ V. Legislation In the United States Zone \\ A. Military Government Zonal Legislation
}

\section{(1) Legal Status and Organization}

The legal basis for Military Government legislation in the four zones is the Four Power Statement of June 5, 1945, ${ }^{1}$ which placed each zone under the authority of its respective commander-in-chief. In the United States zone, this authority was first combined-after the dissolution of SHAEF in July, 1945-with the military command (USFET), General Eisenhower being simultaneously Military Governor and Commanding General with headquarters in Frankfort. ${ }^{2}$ By late 1945, however, the task of government had begun to shift to Berlin where the Office of Military Government for Germany (US) - set up originally to staff the American representation on the Control Council-operated under General Lucius D. Clay as Deputy Military Governor. The coexistence of two Military Government capitals ${ }^{3}$ with ill-defined and

* Part I of this article appeared at 57 YALE L. J. 724 (1948). The same abbreviations used in the footnotes for Part I will be used for Part II: MG for Military Government; AMG for American Military Government; CC for Control Council (Allied Control Authority); SHAEF for Supreme Headquarters Allied Expeditionary Forces (denoting the period of combat and the time immediately following surrender, prior to the partition of Germany into four zones of occupation); USFET for United States Forccs European Theater; OMGUS for Office of Military Government for Germany (United Statcs); MGR for Military Government Regulations (issued by Hq. USFET, OMGUS); OG for Official Gazette (of both the Control Council and Military Government in the United States Zone) ; RGBI. for Reichsgesetzblatt (the official publication of statutes of the German Reich): GVBI. for Gesetz-1nd Verordinungsblatt (the official publication of the Länder of Bavaria and Greater Hesse) ; RegBl. for Regierungsblatt (the official publication of statutes of Land Württemberg-Baden); SJZ for Siiddentsche Juristcnscitung (to date the only law journal in the United States Zone).

$\dagger$ Professor of Political Science and Jurisprudence, Amherst College; Member of the Massachusetts Bar; Special Assistant to the Attorney General, 1942-1944. The author was privileged to serve, from July 1945 to September 1946, as Legal Advisor in the Office of Military Government for Germany (United States), attached as Consultant to the Administration of Justice Branch of the Legal Division in Berlin.

1. Statement of June 5, 1945, by the Governments of the United Kingclom, the United States of America and the Union of the Socialist Soviet Republic and the Provisional Goverument of the French Republic on "Control Machinery in Germany," OG/CC, Supp. No. 1 at 10 (April 30,1945) and Statement of June 5, 1945 by the same governments on "The Zones of Occupation of Germany," $i d$. at 11. See also Report on the Tripartite Conference of Berlin of Aug. 2, 1945, III A (1), id. at 14.

2. See Proclamation No. 1 (USFET) of July 14, 1945, OG/MG, Issue A at 1 (June $1,1946)$.

3. On the organization of MG in the United States Zone see MGR 1.400. For a dis- 
overlapping jurisdictions resulted in friction, confusion and duplication of effort; full efficiency was not obtained until March, 1947, when, after the elimination of USFET, the functions of Commanding General and Military Governor were combined in the Berlin headquarters under General Clay.

The legal relationship between Control Council and zonal legislation has never been officially clarified, nor has any effort been made to assign separate jurisdictions in terms of subject matter. Where there is legislation on the same topic at both levels, action of the Control Council normally takes precedence over zonal legislation. "To the extent that Control Council legislation is effectively enforced, it may be said to exert a harmonizing influence, but otherwise the four zones are treated entirely separately as if they were different states, their administration being the exclusive concern of the occupying power. Dissimilarities in the socio-political aims of the occupiers have made the promised uniformity of treatment a dead letter. ${ }^{6}$

\section{(2) Zonal Legislative Patterns}

Different patterns of the legislative process have evolved within the four zones. German self-government has grown at a slow pace in the British and French zones, the occupation authorities feeling that their objectives could be better reached by imposing on the Germans the institutions and rules necessary to democratic rehabilitation. From the beginning, therefore, regulation of German internal affairs by zonal military government enactment has been much in evidence and is being continued by both British and French despite the establishment of Land parliaments.

An altogether different pattern has developed in the Soviet Zone.?

cussion of the involved history of occupational organization under SHAEF, US Group

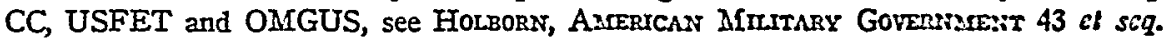
(1947) ; Zink, Axterican Millitary Governarent in Gervinsy 41 ct scq. (1947).

4. Note the creation of two separate types of legislation, $\mathbb{1} \mathrm{GR}$, directed to cceup3tion personnel, and the congeries of proclamations, laws, orders, ordinances, regulations, notices, directives and instructions issued for the guidance of the Germans. ARGR 5.202 sets out the conditions under which each form is employed. See also $\mathrm{MIG} \mathrm{Law} \mathrm{No.} 4$ (effective July 14, 1945), as amended, OG/MIG, Issue A at 17 (June 1, 1945).

Of MGR, Title 5 (Legal and Penal Administration), two editions are used side by side in this article, namely, the earlier one, issued without date in 1945 and 1946, and Change 1, superseding Title 5, issued March 27, 1947. Unless indicated otherwise the quotations in this report are identical in both editions.

5. Summary reports on legislation in the four zones may be found in SIZ. On the organization of the zones see Special Report of the Military Governor US Zone, March 15, 1947, "Governmental Organization in the Occupied Zones of Germany."

6. "The Control Council ... will ensure appropriate uniformity of action by the Commanders-in-Chief in their respective zones of occupation." Four Power Statement of June 5, 1945, OG/CC, Supp. No. 1 at 10 (April 30, 1945).

7. See [1946] SJZ 158 et seq. 
It is hardly possible to draw a clear line of demarcation between zonal legislation issued by the Soviet Military Administration and German Land (or Province) legislation. The method applied is rather indirect, utilizing, as sources of legislation, either the German legislative bodies, or, in consonance with the Soviet preference for executive action, the German administrative authorities. The German territorial subdivisions operate under close supervision of the German Central Administration, established for most legislative fields-including the administration of justice-as early as 1945 in Berlin. These German authorities, amounting in practice to the skeleton of a centralized German administration for the entire Soviet Zone, in turn are under the strict control of the Soviet military administration. Not even the most radical transformations of German economic life, such as the agrarian and banking reforms, are contained in zonal enactments issued for the entire Soviet Zone. When, as a rare exception, the technique of zonal enactment is applied, the act is often not even published, and frequently appears only in parts or abstracts at the discretion of the local military commander.

In the United States Zone, however, the basic policy has been to accelerate transfer of self-government and responsibility to indigenous and democratically constituted German agencies, under continued supervision and control by AMG. ${ }^{8}$ Consequently, AMG zonal legislation confines itself as a rule - there are some notable exceptions-to matters directly conditioned by the occupation objectives, leaving regulation of internal affairs to the German authorities. Of the various sources of legislation operative in the United States Zone- the Control Council legislating for Germany as a whole, the Military Governor for his zone, and the German agencies on the zonal, the Land and the bizonal levels - the Military Governor is decidedly the least significant numerically and, perhaps, also substantially.

\section{(3) The American Approach to Legislative Reconstruction}

At this point, a brief comment on the American attitude toward legislative reconstruction may be in order. Few of the legal staff realized in advance the degree of moral erosion to which Germany had been subjected by the Nazi regime, nor were they educated for the even more exacting assignment of rediscovering under the Nazi rubble the Gestalt of the German social and legal order. Moreover, there was no rational program of legislative strategy, nor were there any tested rules to go by, except the vague principles of democratization and decentralization into which the Potsdam Agreement had frozen an immensely complicated situation.

8. For convenience, American Military Government will be referred to throughout this Part as AMG. 
No wonder, then, that the American lawyers took refuge in and shelter behind the institutions and techniques of home. Rather naively, they believed that the laws of social causation are identical in different environments. An institution not customary at home was basically disliked, one tested considered serviceable. In fairness, it must be pointed out that not a few Americans, willing to learn and learning fast, were able to rise above their national prejudices. But they were decidedly a minority. While in some cases intellectual nationalism may have been justified by the emergency, in others parochial devotion to national environment deliberately disclaimed any intention to absorb the specific ingredients of the German situation. In the legal field, the attitude may be exemplified at random by the diffidence toward the "collectivism" of the integrated $\mathrm{Bar}^{9}$ and the premature insistence on the independence of the judiciary from AMG control, disregarding the serious dangers arising from the traditional deference of the German judge to the letter of the law and his submissiveness to state commands. ${ }^{10}$

In retrospect, it may seem doubtful whether any program of boldly recreating German life in the image of the conqueror could have succeeded in the face of the ingrained social habits of the German people. At any rate, the cleavage between American standards and German realities was considerably narrowed and ultimately became immaterial when, after the initial period of hectic experimentation, the policy of conferring self-determination on the Germans-regarded by many as "too much and too soon"-put the Germans back into the driver's seat. It may well be that the accelerated tempo at which this process was conducted was motivated by the realization that AMG could not gain its objective of imprinting its own pattern on the German mold.

\section{(4) Topical Survey}

A summary survey of the zonal laws enacted by AMIG may illustrate the point that employment of this technique has been generally limited to those situations where occupation policies required uniform action for the entire zone. ${ }^{11}$

Organization. The four Länder were created ${ }^{12}$ and self-government subsequently conferred upon them. ${ }^{13}$ The German bi-zonal agencies called for by the Anglo-American agreements were established. ${ }^{18}$

9. See Holt, Corporative Occupational Organization and Democracy in Germany, 8 Public Adatinistration Review 34 (1948).

10. See Loewenstein, Reconstruction of the Administration of Justice in AmericasOccupied Germany, 61 HaRv. L. Rev. 419, 431 et seq. (1948).

11. AMIG policy has been to leave in effect all legislation not specifically revolsed or altered. See Proclamation No. 1 (USFET) of July 14, 1945, OG/AIG, Issue A at 2 (June 1, 1946) ; MGR 5.203.

12. OG/MG, Issue $A$ at 2 (June 1, 1946), OG/MIG, Issue $C$ at 1 (April 1, 1947).

13. $O G / M G$, Issue $C$ at 1 (April 1, 1947).

14. OG/MIG, Issue $\mathrm{E}$ at 1 (Aug. 1, 1947) and OG/MIG, Issue F, at 1 (Oct. 31, 1947). 
Elimination of Nazism and Militarism. Most of the enactments in this field ${ }^{15}$ either were anticipated or have since been duplicated by Control Council measures. ${ }^{16}$ Law No. 8 of Sept. $26,1945,{ }^{17}$ prohibiting the employment of members of the Nazi party in positions in business other than ordinary labor, was the most vigorous attempt at complete denazification undertaken by AMG. Its subsequent failure contributed to the decision to transfer the denazification process to the Germans. ${ }^{18}$

Restitution. Second in importance only to the denazification issue has been the attempt to make restitution to persons unjustly deprived of property by Nazi action. ${ }^{19}$ For almost two years the Länderrat, with close AMG cooperation, labored over a legally feasible and economically enforceable ${ }^{20}$ law without being able to reconcile the conflicting claims of the persecuted and those claiming subsequent acquisition in good faith. Moreover, monetary compensation for losses of intangible property - such as interrupted professional or artistic careers or pension rights-was impossible so long as there existed no solvent suc-

For text of Proclamation No. 7, on "Bizonal Economic Administration," see OG/MG, Issue I at 1 (Feb. 9, 1948). See also Proclamation No. 8, "Establishment of a German High Court for the Combined Economic Areas," OG/MG, Issue I at 6.

15. Laws No. 1 (SHAEF) on "Abrogation of Nazi Laws," with Regulation under Law No. 1, OG/MG, Issue A, at 3 and 5 (June 1, 1946) ; No. 5 (SHAEF) on "Dissolution of Nazi Party," id. at 17; No. 7 of Oct. 26, 1944 on "Removal from Official Seals of National Socialist Emblems," $i d$. at 20; Ordinance No. 4 on "Prohibition of Wearing of German Military Uniforms," id. at 71; Law No. 154 of July 14, 1945 on "Elimination and Prohibition of Military Training," $i d$. at 152; see also Law No. 153 of May 4, 1945 (SHAEF) on "German Courts Martial," id. at 50, which restricted the jurisdiction of German military court officers of the dissolving Wehrmacht.

16. E.g., Law No. 54 of Aug. 27, 1945 on "Use of Wehrmacht Property," OG/MG, Issue $A$ at 39 (June 1,1946 ), conferred the right to any land formerly held by the $W$ chrmacht, the Reich or the Nazi party upon the government of the Land where located; it was superseded at a much later date by CC Directive No. 50 of April 29, 1947 on "Disposition of Property Having Belonged to Organizations Listed in Control Proclamation No. 2 and Control Council Law No. 2," OG/CC, No. 15 at 275 (May 31, 1947); the two enactments do not completely tally.

17. OG/MG, Issue A at 20 (June 1, 1946) with Regulation No. 1, id. at 21. Sec also Plischke, Dentazification Law and Procedure, 41 Ax. J. INT'L L. 807, 816 (1947) and Loewenstein; Reconstruction of the Administration of Justice in American-Occupied Germany, 61 HARV. L. REv. 419, 449 et seq. (1948).

18. For text of the Law on liberation from National Socialism and Militarism of March 5, 1946, see MGR 24.500. For Bavaria, see Law No. 10, [1946] GVB1. 145; Württemberg-Baden, [1946] RegB1. 75 ; Greater Hesse, [1946] GVB1. 57.

19. The objective, as officially framed, was to insure that "persons and organizations deprived of their property as a result of Nazi persecution should either have their property returned or be compensated therefor, and that persons who suffered personal damage or injury through National Socialist persecution should receive indemnification in German currency." See Directive of July 11, 1947, IV, 17(d), reprinted in 17 Dep'T State Bur.. 191 (1947).

20. For details of the projected legislation, see [1946] SJZ 45, 101, 130, 158; [1947] SJZ 103. 
cessor state or states to assume financial responsibility on behalf of the defunct Reich. ${ }^{21}$ Another factor militating against letting the Germans enact the needed legislation was the understandable reluctance of any German legislator-regardless of his personal attitude towards the "collective guilt" doctrine-to impose a heary economic burden on his people. Faced with these difficulties, and aware of the inadequacy of German law in the related field of denazification, AMIG enacted zonal legislation ${ }^{22}$ on November 10, 1947, the effective date being delayed by an unfulfilled hope that agreement on a uniform law could be reached in the Control Council or at least for the three western zones.

The expertly drafted law ${ }^{23}$ seeks to return to the rightful owners all identifiable and tangible ${ }^{24}$ property unjustly taken, regardless of the cloak of legality that may have been cast over the original transaction. The procedure calls for a civil action before German courts, general supervision and review being exercised by AMIG. Where no heir is available, charitable successor organizations representing the interests of various groups of the victims are to be designated by the occupation authorities. ${ }^{25}$

Economics. Denazification has been implemented in the economic field by controlling certain classes of property, particularly that belonging to the former Reich, to the Nazi party, to persons held under detention, to nationals of states formerly at war with the United Nations and to absentee owners of non-German nationality. Property transferred un-

21. The fines and confiscations of Nazi property accruing under the denazification law are wholly insufficient to cover such claims; for apposite legislation, based on a Lördcrrat project, see Law on "The Creation of a Special Fund for the Purposes of Indemnifiestion"; Greater Hesse, Law of July 7, 1946, [1946] GVBl. 226; Bavaria, Law No. 35 of Aug. 1, 1946, [1946] GVB1. 258. These laws were subsequently revised by the Löndcrrat and made uniform. See [1947] SJZ 285, 407.

22. Law No. 59 of Nov. 10, 1947 on "Restitution of Identifiable Property", OG/MG, Issue $G$ at 1 (Nov. 10, 1947). The law applies to the four Lânder, but not to the American sector in Berlin. Art. 95, ibid.

23. As originally enacted, the law required substantial implementation. The following regulations under the law have been issued: No. 1 of Nov. 10, 1947 on "Establishment of a Central Filing Agency and Manner of Filing Claims for Restitution," OG/MIG, Issue G at 26 et seq. (Nov. 10, 1947) ; and No. 2 of Nov. 10, 1947 on "Filing Reports as Required by Military Government Law No. 59," id. at 30 et seq. (Nov. 10, 1947).

Regulations for the Board of Review under Art. 69 are among the issues awaiting further action.

24. A measure for the indemnification of the victims of Nazism for losses other than of identifiable property and, therefore, not covered by $\mathrm{AG}$ Law No. 59 (e.g. refund of the Jewish property levy of 1938; indemnification for injuries suffered in concentration camps or by other deprivations of liberty; payment of pension rights; repayment of expenses incurred in connection with convictions for racial or political reasons) is under consideration by the Länderrat; see [1947] SJZ 285, 406, 451.

25. It must be noted that while the law grants restoration of title it malies no provision for the transfer in foreign currency of the eventual proceeds obtained, a fault scarcely remediable under present German economic conditions. 
der duress or other techniques of spoliation has also been sequestered. ${ }^{26}$

The Germans, unwilling to believe that the huge Farben combine, symbol and instrument of their economic might, had become a war casualty, continued to trade in its stocks even after a Control Council law ${ }^{27}$ had decreed the seizure of the corporation's property and the dissolution of its organization. An AMG law made all transactions in its securities illegal. ${ }^{28}$

When the occupying powers, after protracted negotiations, failed to agree on an effective decartelization program-clearly a quadripartite objective under the Potsdam Declaration ${ }^{29}$-independent action for the United States zone became imperative. The law, enacted January $29,1947,{ }^{30}$ is to some extent patterned on the Sherman Act and prohibits restrictive and monopolistic practices within the zone and participation by Germans in international cartels. Claiming to be aimed at the destruction of the German war potential and "to lay the foundation of a healthy and democratic German economy," the law is the most incisive intervention in the internal affairs of the defeated people that AMG has undertaken to date. The same objectives served a rather unique measure ${ }^{31}$ which ordered the Minister President of Württemburg-Baden to take immediate steps to separate "in law and in fact"

26. Law No. 52 on "Blocking and Control of Property," OG/MG, Issue A at 24 (June 1,1946 ) with voluminous and frequently changed supplementary regulations (sce MGR 23.332.1 to MGR 23.332.3). See also Law No. 58 of June 29, 1947, on "Implementing Control Council Directive No. 50," OG/MG, Issue E at 16 (Aug. 1, 1947), dealing with the disposition of property once belonging to prohibited Nazi organizations and subsequently seized according to CC Proclamation No. 2 of Sept. 20, 1945, OG/CC, No. 1 at 8 (Oct. 20, 1945) and CC Law No. 2 of Oct. 10, 1945, OG/CC, No. 1 at 10 (Oct. 24, 1945). The technically complicated problem of the so-called "blocked property" cannot be discussed here.

27. Law No. 9 of Nov. 30, 1945 "Providing for the Seizure of Property Owned by I. G. Farbenindustrie and the Control Thereof," OG/CC, No. 2 at 34 (Nov. 30, 1945).

28. Law No. 55 on "Prohibition of Transactions in Stocks, Bonds, and Other Interests of the I. G. Farbenindustrie A. G.," OG/MG, Issue A at 41 (June 1, 1946).

29. III $B(12), O G / C C$, Supp. No. 1 at 15 .

30. Law No. 56 of Jan. 28, 1947, on "Prohibition of Excessive Concentration of German Economic Power," OG/MG, Issue C at 2 (April 1, 1947) with amendment No. 1 of April 26, 1947, OG/MG, Issue D at 5 (June 1, 1947); see also Regulation No. 1, OG/MG, Issue $C$ at 6 (April 1, 1947) and amendment No. 2, OG/MG, Issue I at 17 (March 16, 1948). See also Rasch, Das Verbot iibermässiger Konzentration deutscier Wirtschaftskraft, [1947] SJZ 151.

Order No. 1 issued under Law No. 56 (effective March 8, 1948) OG/MG, Issue I at 6 decartelized the motion picture industry, completely separating production, distribution and exhibition. However, on March 12, 1948, all decartelization (or deconcentration) measures in the American zone were suddenly stopped by order of General Clay, secmingly for political reasons; see N. Y. Times, March 13, 1948, p. 1, col. 4, and March 16, 1948, p. 8, col. 3 .

31. Order No. 1 of Oct. 1, 1947, on "Providing for Disposition of Certain Coal Properties," OG/MG, Issue F at 1 (Oct. 31, 1947). The Minister President was ordered to offer for public sale within thirty days certain specifically named business firms located in Stuttgart and was given elaborate instructions for the management of the public sale and 
certain coal distributors and dealers from any company or organization engaged in mining or processing solid fuels.

A number of specific measures regulate banking; ${ }^{32}$ foreign exchange; ${ }^{33}$ and currency; ${ }^{34}$ another, primarily directed against the black market, prohibits the import of cigarettes and other tobacco products except as authorized. ${ }^{35}$

Finally, in August, 1947, AMIG found it necessary to check the infiltration into German economic life of foreign interests-natural, corporate and governmental-by outlawing transactions between them and domestic interests unless licensed or otherwise authorized ${ }^{30}$ by AMG.

Administration of Justice. Important zonal laws deal with the organization of the courts and the administration of justice, ${ }^{37}$ but the bulk of

the disposal of the proceeds. As a measure of direct operational intervention the act has no parallel in AMG practice.

32. Law No. 57 of May 4, 1947 on "Custodians for Certain Bank Organizations," OG/MG, Issue D at 1 (June 1, 1947) with amendment No. 1 of MIay 6, 1947, OG/MIG, Issue $\mathrm{H}$ at 2 ( Jan. 16, 1948).

33. Law No. 53 (SHAEF) on "Foreign Exchange Control," OG/ArG, Issue A at 36 (June 1, 1946).

34. Law No. 51 on "Currency," OG/MG, Issue $A$ at 23 (June 1, 1946) with amendment No. 1 of July 1, 1947, id., at 15 (Aug. 1, 1947). The latter stipulates that any obligation expressed in terms of any legal tender mark-currency shall be satisfied by payment, mark for mark, of Reichsmarks or Allied military marks. Remembering the disastrous consequences under Weimar of efforts, by courts and legislatures, to ignore inflation, it may be doubted whether this measure has greater merits than those of expediency.

35. Ordinance No. 20 of Nov. 20, 1947, on "Prohibition against the Import of Cigarettes and other Tobacco Products," OG/MIG, Issue H at 3 (Jan. 16, 1948).

36. Ordinance No. 17 of Sept. 2, 1947 on "Prohibited Transactions and Activities," $O G / M G$, Issue $F$ at 4 (Aug. 29, 1947). Mfinor transactions for gifts or charity are not covered. Exempted also are purchases, with lawfully-acquired German currency, for the personal requirements of the purchaser.

37. Law No. 2 on "German Courts," OG/MIG, Issue A at 7 (June 1, 1946); Amendments Nos. 1 of Mirch 2, 1946, id. at 10; 2 of Sept. 9, 1946 on "Limitations upon the Jurisdiction of German Courts," OG/MG, Issue B at 1 (Dec. 1, 1946) and 3 of Mfay 20, 1947 on "Form of Oath," OG/MIG, Issue D at 3 (June 1, 1947); Regulations Nos. 1 of Feb. 16, 1946, OG/MG, Issue A at 11 (June 1, 1946) ; 2 of June 29, 1946 on "Testimony in German Courts by Persons Subject to United States Military Law and by Persons Associated with the United States Office of Military Government," OG/MG, Issue B at 3 (Dec. 1, 1946); 3 of April 5, 1947, OG/MG, Issue D at 4. Note the establishment of the Rhine Navigation Courts by Law No. 9 of July 11, 1947, OG/MG, Issue E at 14 (Aug. 1, 1947). Lav No. 6 of Oct. 4, 1944 on "Dispensation by Act of Military Government with Necessity of Compliance with German Law," OG/MIG, Issue A at 19 (June 1, 1946) exempted acts authorized by AMG from compliance with requirements otherwise existing under German law, a rather superfluous enactment since the supersession of German legislation emanates from the very fact of military occupation.

On the reorganization and operation of the German court system sce Loewenstein, Reconstruction of the Administration of Justice in American-Occupicd Germany, 61 HAIw: L. Rev. 419 (1948). 
zonal measures in this field concern AMG courts and their jurisdiction. ${ }^{38}$ Particularly significant is the establishment of the right of habeas corpus. The writ operates after the American fashion. An AMG court is empowered, for example, to issue habeas corpus where a prisoner is detained more than three days by the occupying authorities without proper arraignment. ${ }^{39}$

Security. Required mainly by military security-primarily in the early stages of the occupation-were measures imposing temporary restrictions on the use of communication facilities, ${ }^{40}$ and administrative regulations concerning curfew, ${ }^{41}$ frontier control, ${ }^{42}$ motor vehicles, ${ }^{43}$ and the possession by Germans of occupation currency. ${ }^{44}$

38. Ordinance No. 1 (SHAEF) on "Crimes and Offences," $O G / M G$, Issue $A$ at 57 (June 1, 1946), with Amendment No. 1 of July 21, 1947, OG/MG, Issue $E$ at 17 (Aug. 1, 1947) ; No. 2 (SHAEF, amended by USFET) on "Military Government Courts," OG/MG, Issue A at 60 (June 1, 1946), with Amendment No. 1 of Jan. 30, 1946, id. at 63, No. 2 of July 21, 1947, OG/MG, Issue E at 18 (Aug. 1, 1947); No. 6 of May 21, 1946 on "Military Government Courts for Civil Actions," OG/MG, Issue A at 73 (June 1, 1946) and No. 18 of Sept. 13, 1947 and No. 21 of Dec. 17, 1947 (Amendments Nos. 1 and 2 of Ordinance No. 6), OG/MG, Issue $F$ at 7 (Oct. 31, 1947) and OG/MG, Isstue $H$ at 5 (Jan. 16, 1948) ; No. 7 of Oct. 18, 1946 on "Organization and Powers of Certain Military Tribunals," OG/MG, Issue B at 10 (Dec. 1, 1946) with No. 11 of Feb. 8, 1947 (amending Ordinance No. 7), OG/MG, Issue C at 11 (April 1, 1947) ; No. 8 of Nov. 5, 1946 on "Milltary Tribunal for Security Violations," OG/MG, Issue B at 16 (Dec. 1, 1946) ; No. 16 of July 11, 1947 on "Military Government Rhine Navigation Criminal Courts," OG/MG, Issue $\mathrm{E}$ at 19 (Aug. 1, 1947).

On Military Government courts in the early period of the occupation see Nobleman, The Administration of Justice in the United States Zone of Germany, 8 FED. B. J. 70, 80 et seq. (1946) ; Nobleman, American Military Government Courts 40 AM. J. INT'L L. 803 (1946).

It may be indicative of the changed relations between victors and vanquished that AMG has recently enacted a law on the jurisdiction of German courts over adoptions by nationals of the United Nations, Law No. 10 of Nov. 28, 1947, OG/MG, Issue H at 1 (Jan. 16, 1948) with Regulation No. 1 of March 13, 1943, OG/MG, Issue I at 15 (March 16, 1948).

39. Ordinance No. 23 of Dec. 31, 1947 on "Relief from Unlawful Restraints of Personal Liberty," OG/MǴ, Issue $H$ at 7 (Jan. 16, 1948).

40. Laws No. 76 on "Posts, Telephones, Telegraphs and Radio," OG/MG, Issue $A$ at 42 (June 1, 1946) ; No. 191 (SHAEF) of Nov. 24, 1944 on "Control of Publications, Radio Broadcasting, News Services, Films, Theatres and Music and Prohibition of Activities of the Reichsministerium fur Volksaufklärtung und Propaganda," id. at 53; Information Control Regulation No. 1 of May 12, 1945 on "Control of Publications, Radio Broadcasting, Films, Theatres and Music," id. at 54. This last was superseded (effective Oct. 3, 1947) by Information Control Regulation No. 3, OG/MG, Issue F at 14 (Oct. 31, 1947) with Amendment No. 1 of Dec. 20, 1947, OG/MG, Issue $H$ at 15 (Jan. 16, 1948) which, in accordance with the German denazification legislation, liberalized considerably the control of AMG over the media shaping and distributing information.

41. Ordinance No. 5 of March 30, 1946 on "Curfew," OG/MG, Issue A at 73 (June 1, 1946).

42. Law No. 161 (SHAEF), OG/MG, Issue $A$ at 53 (June 1, 1946).

43. Ordinance No. 13 of May 4, 1947, on "Regulation of Sale, Transfer, and Registration of Motor Vehicles," OG/MG, Issue D at 1 (June 1,1947); No. 9 of Dec. 31, 1946 on "Motor Vehicle Speed Limits," OG/MG, Issue C at 9 (April 1, 1947) and MGR 23.405.

44. Ordinance No. 10 of Jan. 17, 1947 on "Illegal Possession of United States Mili- 


\section{Conclusion}

It appears from this survey-from which a number of technical regulations are omitted ${ }^{45}$ - that AMG has restricted zonal legislation to the minimum required by the occupation objectives. With the increase of German Land legislation this source has dried up rapidly: that it will flow more freely in the future seems unlikely. If the hoped-for conversion of the Germans to democracy is correlative to the restraint the occupation power imposes on its legislative omnipotence, the American record stands unchallengeable. But the resort of other occupation powers to the more authoritarian method of imposed legislation may seem more realistic to those who realize that to the majority of Germans the process of democratization means little because conducted under compulsion ("unter Zwang").

\section{B. Legislation By Geraran Agencies}

Legislation by German authorities stems from three different sources, the Länderrat, the authorities of the individual Länder and the bi-zonal agencies established in connection with the economic merger of the British and American zones. The increasing rarity of zonal enactments by AMG may lead to the impression that, upon the creation of indigenous German law-making agencies, AMG completely abdicated responsibility for internal legislation. This, however, is not correct. At every stage of the German legislative process, the influence of AMG is manifest, ranging from direct presentation of fully-prepared measures to cooperative assistance and advice in planning and drafting. Although no German legislation may indicate approval by $A M G,{ }^{40}$ a substantial portion of the apparently "autonomous" measures enacted are either initiated or sponsored by AMG or owe their final form to the co-authorship of American and German officials. This technique of legislative tutelage has now fallen into disuse, but while it flourished ithad its full share in the "reeducation" process by which the Germans became capable of assuming the parliamentary responsibilities cast upon them by the new constitutions. ${ }^{47}$

tary Payment Certificates," OG/MG, Issue C at 10 (April 1, 1947) as amended by No. 15 of June 25, 1947, OG/AIG, Issue $E$ at 18. Similar prohibitions apply to British Armed Forces Special Vouchers. See Ordinance No. 12 of Mrarch 8, 1947 on "Tllegal Possession of British Armed Forces' Special Vouchers (BAFSV)," OG/MIG, Issue C at 12 (April 1, 1947) as amended by Ordinance No. 22 of Dec. 18, 1947, OG/MGG, Issue H at 6 (Jan. 16, 1948).

45. To March 16, 1948 (date of OG/MG, Issue I), eight proclamations, twenty-seven laws, one order and three general orders (these pertaining to blocked property under Iaw No. 52), twenty-three ordinances, thirteen regulations, two general authorizations and twenty-four general licenses were issued.

46. MGR 5.210.3.

47. Subject, of course, to the ultimate authority of AMG. See MIGR 5.209.2 and 5.209.3 (5.210.5 and 5.210.6 in Change 1). On legislative review by AAIG see p. 1005 infra. 


\section{LÄNDERRAT LEGISLATION}

\section{(1) Introduction}

The Länderrat has, as discussed earlier ${ }^{48}$ power to legislate uniformly for the four American Länder. Where AMG wishes that a subject be regulated uniformly but desires to avoid action by fiat, or where the Germans appear improperly reluctant to take action on matters patently within their sphere, AMG may suggest or direct Länderrat treatment. No particular formula has developed; indeed, it took more than a year for the Länderrat's dual function-handling legislation suggested or solicited by AMG and also initiating action itself-to become clarified. ${ }^{49}$

So far as measures initiated by the Germans are concerned, two definite stages of development may be discerned, before and after the achievement of Land constitutions. In the earlier period, the Länderrat took up legislation at the request of one or more of the Lander. No definite catalogue of subjects appropriate to uniform treatment was ever formulated, but the twin pressures of widespread economic distress and the general need for uniformity in so small a territorial segment as southern Germany usually produced agreement.

When, under the new constitutions, legislative powers were conferred upon the Land parliaments, a substantial change in procedure was necessary to take account of their competing authority. The first step was to equip the Länderrat with an advisory staff of parliamentarians. ${ }^{50}$ More functional integration is now achieved by submitting to the Länderrat any bill introduced in a Landtag. The Directorate of the Länderrat, its permanent steering committee, actually makes the deter-

48. Legislative powers of the Länderrat-on its development see Part I of this Article, 57 Y AIE L. J. 724-5 (1948)-are derived indirectly from Proclamations Nos. 2 and 4 although neither mentions the Länderrat explicitly. See, however, MGR 5.214.1 (Change 1).

49. The procedure elaborated in MGR 5.214.5 (new in Change 1) clearly separates the two cases.

German initiative: If the Länderrat determines that for a certain matter uniformity is desirable or necessary the proposal (either in the form of a request for a law, or as a fullfledged draft) is sent, by the Regional Coordinating Office and with its recommendations, to the Berlin headquarters of AMG. Copies go also to the Land MG offices. OMGUS, upon examination of the proposal, may decide either that the matter requires "direct exercise of MG authority," that is a zonal law; or that no joint legislation at all on the subject is desirable; or, finally, that the Länderrat should proceed. In any case the Land MG offices are advised of the decision.

$A M G$ initiative: If the matter originates with the Berlin headquarters of AMG (which of course may follow suggestions coming from the Regional Coordinating Office or from the Land MG offices) it requests the Länderrat to submit a proposal. This procedurc is resorted to especially where $\mathrm{CC}$ or bi-zonal matters require implementation by uniform Länder legislation. Thereafter the sequence of steps is the same as if the proposal had originated with the Länderrat.

50. The Parliamentary Advisory Committee. 
mination of whether a measure should be handled on the Lïnderrat level or left to Land action.

\section{(2) Processing}

Within the Länderrat machinery-embracing some sixty-odd permanent or semi-permanent committees-the Legal Committee is the workshop, the drafting agency and the clearing house for all legislation. ${ }^{51}$ Its procedure is kept flexible. When a project reaches the Committee, one of the Länder is usually designated as reporter and charged with submitting a first draft and steering it through subsequent discussion. Where a project is not the exclusive concern of the Legal Committee, close cooperation is maintained with the functional committee interested. Liaison is likewise maintained with the bi-zonal Committee for Economic Law and, in some cases, drafts are prepared jointly. ${ }^{.2}$

The success of American-German cooperation in the Lünderrat and its committees depends much on the psychological skill of both partners and even more on the knowledge of German affairs possessed by American officials, a commodity of which there has been no abundance. Cooperation of the German officials-almost without exception capable and well-informed men and women-has left nothing to be desired. They have been eager to acquaint themselves with the mental processes of the conquerors and to profit by their better understanding of the ways of democracy. To observe how the waters of the Mississippi and the Hudson mixed-or failed to mix - with those of the Isar and the Neckar was a remarkable experience. In practice, various cooperative techniques have developed. American officials either sit down with the Germans in the drafting stage or examine and revise drafts prepared by the Germans alone. On the whole, the relationship has been one of healthy give and take. It is to the credit of both that the Germans have not resented American tutelage and the Americans have not imposed their opinions. ${ }^{53}$

But had the American policy of non-intervention been less rigid, more

51. The Minister of Justice of Greater Hesse is chairman, ex officio, of the Legal Committee. MGR 5,427 .

52. Representatives of the Berlin Legal Division and German and British officials from the British Zone-since the beginning of 1947-also regularly attend mectings.

53. In due course, the German officials in the Lönderrat gained so much self-reliance that on various occasions they either objected to revisions the Americans desired or politely -though firmly-rejected proposals outright. Mfore often than not, their attitude was substantially justified. For example, the second drait of the Law for the Punishment of National Socialist Crimes (for text see Greater Hesse, [1946] GVB1. 136) proved unacceptable to the Legal Committee because of faulty drafting, aggravated by a faulty German translation; the Legal Division in Berlin, responsible for both, promptly yielded. A draft proposal by the Legal Division concerning the registration of shares and similar commercial documents, intended to "deconcentrate" economic power, was, for technical and substantial reasons, so strongly objected to by the Legal Committee (see [1946] SIZ 102, 192) that AXIG did not in- 
of American experience could have been infused into German institutions at a time when they were not yet hardened into the traditional mold. The procedure of subtle persuasion soon was largely neutralized by the insistent if unobtrusive efforts of the conservative German ministerial bureaucracy to minimize any departure from habit. This is not meant as an adverse reflection on the general attitude of the Germansbut by the extreme policy of non-intervention on the part of AMG certainly a major opportunity for substantial legislative reform has been lost.

\section{(3) $A M G$ Review}

Whenever the Länderrat in one of its monthly formal sessions passes a measure, it is submitted for approval to AMG headquarters in Berlin unless, as has happened in exceptional cases, the Military Governor, usually present at the meeting, approves the act on the spot. A Länderrat-adopted law may be rejected by AMG because uniformity is considered either undesirable or not required by a basic occupation objective. Equally, of course, approval may be denied because the proposed measure violates democratic principles. ${ }^{54}$ Where a Länderrat-adopted law is rejected by AMG, it does not become a dead letter but is referred to the Landtage for action.

\section{(4) Enactment}

On approval of a bill by AMG, each of the Minister Presidents is under a formal obligation to promulgate the law by decree without prior reference to his parliament. ${ }^{.5}$ Prior to the establishment of constitutional governments, all a Minister President needed was to persuade his cabinet-appointed, like himself, by AMG-of the wisdom of the measure. Now, however, he runs the serious danger of being required to promulgate a law and subsequently discovering that the parliament of his Land disagrees sharply. This may explain the recent

sist on it. In the draft law on the press, under preparation for a year by a special committce of the Läıtderrat, an American-inspired provision requiring public agencies to inform the press on matters of public interest was found so much in conflict with bureaucratic authority that it finally was stricken, see [1946] SJZ 243; AMG could and did slip it, however, into §12(1) of the Law on Public Officials for Greater Hesse [1946] GVBI. 205. The most strenuous protest the writer witnessed occurred when the Food and Agriculture Division-without consulting the Legal Division-confronted the Legal Committee with a wholly amateurish and unworkable land reform proposal; for text of the entircly revised law, see: Greater Hesse, [1946] GVBl. 218; Bavaria, [1946] GVBl، 326; see also [1946] SJZ 242.

54. On the procedure followed in Berlin, see pp. 1014-6 infra.

55. Proclamation No. 2 of Sept. 19, 1945, OG/MG, Issue A at 2, Art. III (2) : "Until - such time as it is possible to establish democratic institutions it will be sufficient for the validity of state legislation that it be approved and promulgated by the Mirister President." See also MGR 5.214.1 (Change 1). 
curious phenomenon of Minister Presidents failing to validate laws by promulgation. ${ }^{56}$

\section{(5) Legislation Enacted}

By the beginning of 1947, some thirty-odd major legislative projects were approved by the Länderrat and many more have since come under consideration. A full-scale topical survey would exceed the available space, but the following selective enumeration may indicate the range and type. ${ }^{57}$

Undoubtedly the most important assignment given the Lïnderrat has been denazification. An attempt was made to solve the problem by the Law of March 5, 1946, ${ }^{58}$ the statute emerging from intense GermanAmerican cooperation in both planning and drafting. Subsidiary denazification measures likewise have been processed through the Lïnderrat to insure if possible uniform execution of policies. Suitable to include in this category are the various laws for the redress of National Socialist iniquity in the administration of criminal justice, and the punishment of Nazi crimes. ${ }^{59}$

In the field of legal reform proper, substantial attention has been given to both substantive and procedural problems, ${ }^{10}$ the maintenance

56. Promulgation has been both delayed and omitted altogether. For example, the Lawyers' Code, approved by the Länderrat in Sept. 1946, has entered into force only in Bavaria. See Law of Nov. 6, 1946, [1946] GVB1. 371. Hesse and Württemberg-Baden have not yet acted. See also instance cited in note $63 \mathrm{infra}$. The reasons for such non-compliance are not known to the writer. It may be that in a specific case the Minister President felt that the matter should be postponed until the Land legislative body could pass on it, although this is quite out of order since Landerrat legislation is beyond the pale of Lordtag jurisdiction. For a long time, AMG was not aware of the situation; but it appears that efforts are now being made to persuade the Länder to comply more promptly with Ländcrrat decisions.

57. Reports in Länderrat legislation are found currently in SJZ. For a survey, see Römer, Wiederaufbaus des Rechts, Eisz Rïckblick [1947] SJZ 94.

58. For text, see Bavaria, Law No. 10, [1946] GVB1. 145 et seq.; WürttembergBaden, [1946] RegB1. 75; Greater Hesse, [1946] GVBI. 57; AIGR 24.500.

59. Bavaria, [1946] GVBl. 180; Württemberg-Baden, Laws of $\mathrm{M}$ [ay 31, 1946, [1946] RegB1. 205; Greater Hesse, Laws of Miay 29, 1946 [1946] GVBI. 136.

60. E.g.: A measure permitting judicial settlement of insolvency conditioned by ceonomic circumstances beyond the control of the debtor, for Bavaria, Law No. 26 of April 25, 1946, [1946] GVB1. 197; Greater Hesse, Law of Aug. 24, 1946, [1946] GVBl. 170; legal remedies, Bavaria, Law No. 43 of April 10, 1946, [1946] GVB1. 300, Württemberg-Baden, Law No. 27 of April 25, 1946, [1946] RegBl. 221, Greater Hesse, L3w of Sept 9, 1946, [1946] GVB1. 174; administrative courts, Bavaria, Law No. 39 of Sept. 25, 1946, [1946] GVB1. 281; Württemberg-Baden, Law of Oct. 16, 1946, [1946] RegBl. 221, Grester Hesse, Law of Oct. 21, 1946, [1946] GVBl. 194. These laws on administrative courts are noteworthy because they achieve uniformity in all three Länder-in spite of some loeal differences in organization-for the first time in German history.

Also, a law on the organization of the bar (promulgated only by Bavaria, Law of Nov. 6, 1946, [1946] GVB1. 371); repeal of the law for the prevention of the abure of methods of legal enforcement, for Württemberg-Baden, see Lav No. 90 of Sept. 11, 1947, 
of legal uniformity being a primary concern. In this area, a number of Control Council measures have required Länderrat implementation. ${ }^{01}$ The bulk of legislation, however, deals with the impact of war and defeat on the economy of the devastated country. ${ }^{62}$ Most controversial of the laws enacted to meet the emergency situation was that requiring licenses - to be issued only on proven economic necessity-for the establishment of new enterprises and subsidiary offices and plants. ${ }^{03} \mathrm{An}$ other major issue has been how to handle preliminary registration and determination of claims against public bodies-Reich, states, munic-

[1947] RegBl. 93; elimination of the public prosecutor from civil law suits, for Württemberg-Baden, see Law No. 92 of Sept. 11, 1947, [1947] RegB1. 93; reintroduction of lay assessors (Schöffen) in criminal trials, for Württemberg-Baden, see Law No. 99 of Sept. 11, 1947, [1947] RegB1. 96; interruption of law suits in view of impending legislation (text and quotations not available); consequences arising from the fact that the legal end of the war cannot be determined, for Württemberg-Baden, see Law No. 97 of Scpt. 11, 1947, [1947] RegB1. 96.

61. E.g., CC Law No. 16 of Feb. 20, 1946, OG/CC, No. 4 at 77 (Feb. 28, 1946), which repealed the Nazi marriage law of 1938 , and declared in $\$ 79$ that "all provisions of any carrying-out laws, ordinances or decrees and of any other legislation which are inconsistent with the present law are also hereby repealed." Doubts arose as to whether in the German translation the phrase beginning with the word "which", refers only to the words "any other legislation," or to the entire preceding sentence. (No such doubts existed in the mind of the present writer who drafted the English text of the law and wrote its German translation.) The Legal Committee of the Länderrat properly undertook a systematic investigation of the validity of all legislation coming under $\$ 79$; see [1946] SJZ 130. The Länderrat likewise legally recognized common-law marriages contracted under the Nazi regime between couples persecuted on racial grounds; sce [1947] SJZ 47, 226, 287, 406.

62. Among the measures in this field deserving mention are those on indemnification of persons injured in military service, Bavaria, Law No. 64 of March 26, 1947, [1947] GVB1. 107, Württemberg-Baden, Law of Jan. 21, 1947, [1947] RegB1. 7, Hesse, Law of April 4, 1947, [1947] GVB1. 19; compulsory contributions of services and goods during the present emergency, [1947] SJZ 286, 406, 451; representatives of all three Western zones participated in the elaboration of this measure. Also: conscription of work-dodging youth for labor service, [1947] SJZ 407, 451; misappropriation of gift parcels sent from abroad, Württemberg-Baden, Law No. 95 of Sept. 11, 1947, [1947] RegB1. 94.

63. See Bavaria, Law No. 39 of Sept. 23, 1946, [1946] GVB1. 279, Hesse, Law of June 24, 1947, [1947] GVB1. 38; see also [1946] SJZ 75, 101, 131, 242. Promulgation in Hesse was deferred, seemingly to allow reconsideration by the Landtag. In its final version, the Hessian law differs considerably from that agreed upon by the Länderrat. Sec [1947] SJZ 449.

Although the law is palpably authoritarian in character-the Läıderrat Legal Committee and some officials of the Berlin Legal Division protested on the ground that the law continued the rigid state controls on business established by the Nazis, see [1946] SJZ 75-the Economics Division of OMGUS insisted on it because supposedly required by the chaotic conditions of a disorganized economy. As could have been foreseen, the law is being used by local vested business interests to throttle competition and also permits arbitrary discrimination against victims of Nazism and expellees wishing to start business. In view of the harmful results of the law-in Bavaria, within seven months after its coming into force, of 9,117 applications, 5,248 were granted, 2,017 denied, and 1,852 postponed - rescission by AMG is under advisement. See N. Y. Times, Dec. 21, 1947, p. 14, col. 1. 
ipalities and others-which, under AMG law ${ }^{64}$ cannot be entertained by German courts.

Of vast political implication has been the initiation of an incisive agrarian reform. ${ }^{65}$ Farms above 100 hectares (about 240 acres) must surrender, against compensation, a progressive portion of the excess land, the objective being resettlement of some of the Germans compulsorily transferred from the east. Still further in aid of these expellees, the Länderrat, under instructions from AMIG, enacted a law assimilating those of German descent to the status of German nationals..$^{\text {Cs }}$

And, finally, legislation on the press and other communications media attempts the difficult reconciliation of the democratic postulate of free expression with the controls commensurate with an unbalanced political mentality ${ }^{67}$

\section{(6) Appraisal}

An appraisal of the first two years must conclude that, as a pragmatically evolving substitute for a common parliament and government of the zone, the Landerrat has proved its usefulness if not its indispensability. ${ }^{68}$ The major achievement has been the maintenance of a modicum of legal unity in the face of the natural tendency of a collapsed country to break into fragments of sovereignty, and this not only in the fields of private and criminal law previously covered by Reich legislation but also in many economic matters. And, through the medium of the Länderrat, efforts have been made at inter-zonal cooperation. ${ }^{69}$

64. See Law No. 2 on "German Courts," $\$ 10(\mathrm{~g})$, OG/MG, Issue A at 7 (June 1, 1946) ; see Loewenstein, Reconstruction of the Administration of Justice in AmeriearOccupied Gernany, 61 HARv. L. Rev. 419, 425 (1948). See also [1947] SJZ 101.

65. Bavaria, Law No. 48 of Sept. 18, 1946, [1946] GVB1. 326; Greater Hesse, Law of Oct. 15, 1946, [1946] GVB1. 218.

66. Bavaria, [1947] GVB1. 51; Württemberg-Baden, [1947] RegB1. 15; Hesse, [1947] GVB1. No. 2.

67. This subject occupied the Legal Committee and American officials for more than a year. Separate laws deal with the press proper; the licensing of publishers, newspapers, magazines and the producers of entertainment (theaters, films, music); and the distribution of newsprint to magazine and book publishers. The group of laws was submitted to the consultative parliamentary bodies of the Lältder in October, 1946. When the laws were adopted by the Länderrat in November, 1946, the proviso was added that they would expire on March 31, 1947 unless continued by the newly elected Lasditage; see [1946] SJZ 243. The writer does not know whether the Land parliaments approved them in time.

68. For documentary material concerning the Länderrat see PoLrock Azid MFEISE, Gerarany under Occupation 126 et seq. (1947). Sec also Loewenstein, Political Reconstruction in Germany, Zonal and Interzonal, in CaANGe ANo Crisis mi Europan: GovERNMENT 36 (Pollock ed. 1947); Cassidy, The Beginning of Self-Goecrmment in the American Zone of Germany, 16 Dep't State Buth. 231 at scq. (1947).

69. For example the settlement of the debts of the former Reich, to which the 
But the Länderrat, initially created by AMG as an emergency agency for intra-zonal coordination, was a hybrid institution from the beginning. Had the American policy-makers been less fascinated by the Potsdam postulate of maximum decentralization, it would have been none too difficult to develop this framework of state cooperation into a full-fledged federal government for southern Germany, with immeasurable consequences for the political reconstruction of the western zones as a whole. But in time the resurgence of "states rights" sentiments - particularly in Bavaria, ever given to separatism, and, quite surprisingly, in the new, synthetic state of Greater Hesse-began to impede the operation of the Länderrat as a skeletal government for the zone. Moreover, AMG policy, although at the outset strongly favoring Länderrat action, has evidently switched. During 1947, an increasing number of laws were returned without approval for no other reason than that uniform legislation, although desirable, did not seem required. ${ }^{70}$ Unquestionably, this change has largely been motivated by a desire not to impair the prestige of the democratically-elected Landtage through wide use of the decree powers of the Minister Presidents; but in view of the enormous work-loads those bodies already carry it would seem wise to ease their burden by a reasonable delegation of powers. The parliaments seem undecided whether their drive for independence or the need for uniform legislation ${ }^{71}$ should primarily determine the measure of their acquiescence to Länderrat action. The Land constitutions, while reluctantly recognizing the existence of intraand inter-zonal agencies, limit sharply the validity of their actions for the individual Länder. ${ }^{72}$

The constitutional twilight zone in which the Länderrat has been operating almost from its inception has lately deepened. While, under

Länder do not consider themselves legal successors, was submitted to an interzonal conference in which representatives of the three western zones and of Berlin participated; see [1947] SJZ 101.

70. Among the laws found not mandatorily requiring uniform treatment were: an amendment to the Reich law on missing persons, a law recognizing common-law marriages begun during the Nazi regime but not officially sanctified because of racial persecution, and a law invalidating posthumous marriages. See [1947] SJZ 405 et seq. Tho posthumous marriages were permitted under Nazi law to SS and Wehrmacht men killed in battle, the purpose being to legitimatize their offspring and to grant wives and children the status of heirs. See also [1947] SJZ 50. A difficult situation has, however, been created by the refusal of the Länderrat to accept refusal by AMG as final. In a few cases, the German authorities have deliberately re-enacted a rejected statute. The extent of AMG's perseverance is not yet known.

71. As indicated in the constitution of Hesse, Art. 151(2): "In particular, the existing unity of law must not be encroached upon without compelling reasons. Legislation determines whether or not a compelling reason is present." See also Art. 152(1) and [1947] SJZ 404, 451.

72. See Bavaria, Const., Art. 180: the State Government is authorized, "so far as it is absolutely necessary" and with the approval of the Landtag, to transier jurisdiction 
continuing AMG policy, the Minister Presidents are permitted to enact uniform laws for the Länder by virtue of their decree powers, they run the risk of parliamentary censure if a Landtag happens to disagree with a measure so enacted. ${ }^{73}$ If the Landerrat acts-as it does quite frequently-merely as the drafting agency for bills to be submitted to the Landtage for uniform adoption, the latter are constitutionally free to amend or even to reject such measures. Employment of this power has increased legislative disunity. ${ }^{74}$

Moreover, a number of intricate constitutional issues have been raised by the creation of Land legislative bodies. ${ }^{75}$ Does a zonal law possess a higher rank than a Land law if both pertain to the same subject matter? Although the logical answer is in the negative-since a Landerratmeasure is merely a cumulation of individual Land laws-the Länderrat has affirmed its authority by declaring that a Landtag may not amend or repeal a zonal enactment. ${ }^{76}$

The most serious danger, however, to the continued existence of the Länderrat arises from the bi-zonal agencies. Initially, their limited jurisdiction did not affect the need for zonal agencies. But recently their legislative activities, extending to all economic matters, ${ }^{\pi}$ have become so pervasive that competent German observers are inclined to believe that the Länderrat will shortly be left with jurisdiction solely over matters of law in the technical sense (Justisgesetze). is If the new

"to the Council of Minister Presidents or other joint agencies of several states or zones," but only in the fields of foreign relations, economics, finance, food, transportation and communications. Hesse, Const., Art. 152 permits agreements of the Hessian government with other governments "for certain definite fields of law" only, but such agreements require approval of the Landtag. Laws enacted by such bodies bind the State of Hesse only when within the limits of the Constitution. Württemberg-Baden, Const., Art. 105, while ignoring the Länderrat completely, agrees to the Land's submission to inter-zenal bodies only and restricts acquiescence "especially to the fields of forcign relations, cconomics, food, finance and transportation" (the omission of communieations may be ascidental). In this case the government, however, is responsible to the Lasdlog for its activities and the votes in these organizations. The constitution of Bremen is silent on the entire issue.

73. MIGR 5.214.5 (Change 1); Württemberg-Baden Const., Art. 106(2). See also [1947] SJZ 101. When a law is promulgated with AMIG authorization by a Xlinister President, its preamble states that it is promulgated "upon examination" by the Parliamentary Advisory Committee and "on the basis of Art. II and III of Proclamation No. 4 of MIarch 1, 1947, in conjunction with Proclamation No. 2 of Sept. 19, 1945."

74. For example, the law of trusteeships for blocked and heirless property, [1947] SJZ 102, 225, 286, 449, was drafted as a zonal measure to be submitted to the Landioge for uniform adoption; it was considerably changed by the Bavarian parliament, Law of June 19, 1947, [1947] GVB1. 143.

75. See [1947] SJZ 102, 404, 450.

76. [1947 SJZ 450.

77. See Proclamation No. 5 of June 2, 1947 on "Economic Council," Arts. I (2) and II, OG/MG, Issue F at 1 (Aug. 1, 1947); Proclamation No. 7 of Feb. 9, 1948, on "Bizonal Economic Administration," Art. III, OG/MIG, Issue I at 1 (March 16, 1943).

78. See [1947] SJZ 407, 450 et seg. 
plan for the reformed Economic Council-to which, as a sort of second chamber, a new organization styled again a Länderrat, is added ${ }^{70}$ proves successful, and if a bi-zonal department of justice is established, it will conclusively be shown that the period of the Länderrat's service has come to its end and that the body should be scrapped.

\section{LAND LEGISLATION}

\section{(1) Basis of Authority}

In accordance with the basic occupation policy of restoring selfgovernment to the Länder in the American zone as early and as widely as possible, AMG transferred legislative autonomy to the Minister Presidents in the fall of $1945 .^{80}$ In the subsequent pre-constitutional period, Land legislation depended only on approval and promulgation by the Minister President - though subject to the authority of AMGand was strictly authoritarian, the consultative assemblies appointed in each Land $^{81}$ being mere public forums. Under their new constitutions the Länder are endowed with full legislative powers ${ }^{82}$ subject only to "international agreements to which the United States is a party; quadripartite legislation and powers reserved to $\mathrm{MG}$ in order to effectuate basic policies of the occupation." 83 The new constitutions assign the legislative power to the Landtage and the people. ${ }^{84}$

\section{(2) Initiative and Procedure}

The official gazettes of the Länder fail to reveal whether a particular law reached the statute book by German efforts alone or with the help of American pilots. As on the Länderrat level, AMG evolved for German Land legislation an empirical procedure of American-German co-authorship, another application of the legislative tutelage characteristic of the American zone.

Only once has AMG legislated by outright dictation. The Minister

79. See Proclamation No. 7 of Feb. 9, 1948, on "Bizonal Economic Administration," Arts. IV and V, OG/MG, Issue I at 1 (March 16, 1948).

80. Proclamation No. 2 of Sept. 19, 1945, Art. II (1) and (2), OG/MG, Issue A at 3 (June 1, 1946) ; see also MGR. 5.209.1 and 5.209.4.

81. See Greater Hesse, Preliminary Constitution of Nov. 22, 1945, Art. 9, [1945] GVB1. 23; Württemberg-Baden, Law of Jan. 10, 1946, [1946] RegB1. 29.

82. A measure of the extent of this freedom may be found in the power in the German bodies to modify or supersede AMG legislation with the exception of that cnacted by SHAEF, USFET, OMGUS and EUCOM (European Command). Such action of course requires AMG approval, but it has been necessary to modify or rescind some AMG legislation at $L$ and and subordinate levels. See MGR 5.213, Change 1.

83. AMG still retains, of course, the power to order legislation promulgated by the Minister Presidents. See Proclamation No. 4 of March 1, 1947, Art. II, OG/MG, Issue C at 1 (April 1, 1947).

84. For Bavaria, see Const., Arts. 70-6; for Württemberg-Baden, Const., Arts. 81-6; for Hesse, Const., Arts. 116-25. 
Presidents were ordered, without any previous consultation, to enact a revised text of the code of criminal procedure drafted by AMG legal officials. Justification for the procedure lay in the need to reopen German courts to administer criminal justice in accordance with democratic standards. But the experiment in dictated legislation has not been repeated..$^{85}$

A different technique was employed for a number of urgently needed legislative reforms for which, for obvious reasons, the Länderrat machinery could not be used. The process-"legislative artificial insemination"-was set in motion by a directive on a specific subject issued by Berlin headquarters and addressed through the Land ANIG Offices to each of the Minister Presidents, requesting them to submit Land laws drafted according to given specifications. The Germans learned from these instructions the minimum democratic standards they had to observe but were permitted enough latitude to individualize the drafts in line with local traditions and requirements. The method was utilized by whatever functional branch of AMIG desired German legislation. Conferences were held, in Berlin or in the capitals of the Länder, between military officials and German delegates from one or several of the Länder..$^{86}$ This technique was applied in particular to the legislation by which, in sucessive stages, the statehood of the Länder was revived and their political structure created. The cram course in the art of self-government thus given the Germans-cynics termed it the "six-day bicycle race for democracy"- was crowned by the drafting of the new constitutions by elected conventions and their adoption in the latter half of 1946. By that time, AMG's policy of non-intervention in German internal affairs had become so rigid that, provided the charters conformed generally to democratic standards, the Germans were at complete liberty to adopt whatever structural arrangements theyr desired. ${ }^{87}$

The technique of American-sponsored legislation, considered inconsistent with parliamentary government under the new constitutions,

85. The Lawyers' Code, likewise wholly an American drait, was processed through the Läıderrat after consultation with the Germans. See Loewenstein, Reconsiriction of the Administration of Justice in American-Occupicd Germany, 61 Hanv. L. REv. 419, 457 (1948).

86. Occasionally, the process was complicated in ironic fashion. For esiample, adequate accommodation and feeding of German officials coming to Berlin on official business for a long time proved beyond the capacity of AMG in spite of an Interdepartmental Committee laboring over the issue for many months.

87. An Interdepartmental Committee of Berlin headquarters reviewed the various drafts article by article. Top officials of the Civil Administration Division, delegated as observers and unofficial advisors to the capitals of the Länder, were limited to minimum interference with content and form of the planned instruments. Mfembers of both groups at times entertained considerable misgivings on both individual provisions and the workability of the constitutional project as a whole. ANIG informally raised objections to 
is now no longer employed. The mechanism of German-initiated legislation began to function slowly under the decree powers of the Minister Presidents, gathered momentum in 1946 and, by the time the new constitutions entered into effect, had become the most important source of legislation. As a rule, AMG becomes officially cognizant of laws developed exclusively by the Germans in the subsequent process of review, examination and approval.

\section{(3) $A M G$ Review}

In the pre-constitutional period, examination of Land legislation was the function of the Director of the Land AMG Office ${ }^{88}$ who was instructed "to examine all legislation . . . for the purpose of determining whether any provision thereof is in conflict with the policies of MG or will have any substantial effect outside the area to which its application is limited." The Director could approve, suspend or repeal legislation, reference to higher authority being necessary only where he felt doubtful-which he rarely did. This arrangement of decentralized supervision of Land legislation proved to be an organizational error, intensified by the split-personality of headquarters, jurisdictionally divided between the military command (Frankfort) and the Military Governor (Berlin) ${ }^{89}$ The dynamics of bureaucracy being what they are, Frankfort was wholly disinclined to consult or even inform Berlin in the rare cases of doubtful legislation referred to it. Thus, Berlin usually heard of new laws only when the Land AMG offices submitted their monthly reports, ${ }^{90}$ long after the legislation had taken effect. The lapse was productive of numerous embarrassing consequences. ${ }^{91}$ Fur-

a number of provisions as incompatible with democratic principles. The constituent assemblies accepted appropriate amendments. In the case of Art. 41 of the constitution of Hesse (providing for the nationalization of certain natural resources and rail communications), General Clay insisted on holding a separate referendum.

All constitutions were finally approved by AMG with an official interpretation concerning some controversial provisions. For details see letters addressed by Gencral Lucius D. Clay to the presidents of the constitutional conventions of Oct. 21, 24, 29, 1946 respectively. They are reprinted in a booklet containing the texts of the constitutions, issued by OMGUS on Feb. 15, 1947, pp. 5, 32, 56.

88. MGR 5.209.3.

89. The chaos resulting, in the early period, from the competitive existence of two AMG capitals, Berlin and Frankfort, has been noted by many observers; see, c.g., ZINK, American Military Government in Germany 53 et seq. (1947); Hul, Struggle for Germany 105 et seq. (1947); Knappen, And Call it Peace 80 (1947).

90. MGR 5.213 and 5.948 (MGR 5.900.1 in Change 1). For a long time the only source of information available to the Legal Division in Berlin concerning Land legislation planned or submitted for approval to the Land MG Offices consisted in unofficial contacts that the writer had clandestinely established with officials in the German Ministries of Justice.

91. For example, the promulgation of a wholly premature "Fundamental Charter" of Greater Hesse, [1945] GVB1. 23, was approved by the Land AMG Office in Wiesbaden 
ther difficulties were caused by the fact that it was virtually impossible to keep Land AMG informed of higher level policy decisions. Accordingly, the comparatively indifferent Land offices rejected only those measures which contained palpably iniquitous provisions, completely unaware of whether the Länder were arrogating to themselves functions reserved for Control Council or zonal action.

Little harm was done so long as Land legislation was mostly of a technical, administrative nature, designed to set the basic services of the state in motion. But with the progressive transfer of legislative initiative to the Minister Presidents acting under their own responsibility, ${ }^{92}$ the absence of a centralized system of supervising Land legislation became more serious. Moreover, deteriorating economic conditions caused many acts of the individual Länder to have effect outside the area to which their application was limited.

The result of this lack of coordination was that the Legal Division of Berlin headquarters was repeatedly compelled to inhibit the promulgation of legislation or, if it had been published, to prevent its distribution. ${ }^{93}$ Frequently, it was too late for either action. What is perhaps more important, failure to concentrate approval of Land legislation in Berlin headquarters produced excessive legislative diversification.

When legislative sovereignty was conferred upon the Iänder under their constitutions, the existing controls were further eased because deemed inconsistent with the basic American policy of minimum interference in German internal affairs. ${ }^{94}$ An important concession was made to German self-government in that the validity of Land. legislation is no longer dependent on approval by ANG: "the submission of such legislation . . . shall not . . . prevent the coming into force of legislation in normal course unless MG orders otherwise." ${ }^{95}$ In view of the

without referring it to Berlin which learned of its existence only through the German Press. For weeks no authentic text (published in Wiesbaden by posters only instead of in a law bulletin) was obtainable in Berlin. In another field a comparable difficulty arose when the AMG detachment of Minich licensed a monarchist political party without bothering to consult the Land AMG Office on the other side of the river, let alone to inform Berlin. When civilian officials in Berlin, aware of the damaging consequences of such diluted authority, tried to remonstrate they were advised by their military betters that, under the rules and conventions of the military establishment, the individual offeer is authorized to act within the limits of his assignment, and that "if and when" he commits an error in judgment he can be transferred or replaced.

92. MIGR 5.209.4.

93. A pertinent illustration was the approval, by an AMG official ignorant of loeal conditions, of an undemocratic and reactionary Bavarian law on religious cducation.

94. See Directive to the Military Governor of July 11, 1947, IV (12), instrueting him "to exercise the power of disapproval over German legislation only when such legislation conflicts with the legislation or other policies of MIG." 17 DEP'r STATE BuIL 190 (1947); see also MIGR 5.210.1-3 (Change 1).

95. MGR 5.210 .5 (Change 1 ). 
Land constitutional provisions, ${ }^{96}$ it is impossible, in the vast majority of cases, to complete review in the brief period between a measure's submission and its effective date.

After two years of uncoordinated efforts, the reviewing procedure has been streamlined. ${ }^{97}$ In the Berlin Legal Division, a special Legislation Branch has been established among whose functions exercised through the Liaison and Review Section, is that of maintaining contact with the German authorities ${ }^{98}$ and reviewing Land legislation. Upon receipt of the enacted law, ${ }^{99}$ the Section solicits comments from the interested functional divisions of headquarters and if no objections are raised, decides on no further action. A steady flow of Land legislation-from five to ten individual laws weekly-sluices through this mill; and the time lag between enactment and completion of review has been shortened to about two or three months.

In case an objection is raised, or when major policy decisions are involved, the law is submitted to a Legislation Review Board. ${ }^{100}$ The Board receives all Land measures so challenged and all Länderrat acts on which staff studies are made. Serving, then, as a sort of clearinghouse for all types of legislation, ${ }^{101}$ it is charged with the final decision on whether the legislation should be allowed to stand, should be modified or must be scrapped. In view of the general policy of interfering as little as possible with the German legislative sovereignty, disallowance is the rare exception. ${ }^{102}$

96. For example, under Bavarian Constitution, Art. 72, "laws are voted by the Landtag or by the people." Under Art. 76 "laws passed in compliance with the constitution are promulgated by the Minister President and are upon his order published within a wcek in the Bavarian Official Gazette. Each law must fix the date on which it will enter into force." "Enactment", thus, is the passage by the Landtag.

97. However, the reviewing procedure is still far from being simple. It is dispersed among no fewer than three agencies of AMG with competing jurisdictions, namely the Land MG Office, the Regional Coordinating Office, and Berlin. See MGR 5.210.5, 5.210.6 and 5.210.8 (Change 1).

98. The Land MG Offices are instructed to keep Berlin informed on pending legislation, but are usually unable to comply fully because of the manpower shortage.

99. MGR 5.210.5 (Change 1); the procedure begins with the submission of a true copy by the Minister President to the MG Land Office "immediately upon its enactment and prior to its entering into force." Copies are sent by the Land MG Office to the Legal Division in Berlin and to the Regional Coordinating Office in Stuttgart.

100. It is composed of the Legal Director, the Directors of the Civil Administration and the Internal Affairs and Communicitions Divisions, and of a representative of the Offices of the Political Advisor and of the Secretary of Staff.

101. For some time an interdivisional competition has been under way, the Civil Administration Division trying to freeze out the Legal Division which has heretofore been primarily responsible for the examination of Land legislation. The move has succeded in Bavaria and Württemberg-Baden, not yet in Hesse, and only partially in Berlin.

102. Recent instances of nullification, occurring after the enactment of the constitutions were (according to private information): a measure exempting the pay of members of the Hessian Landtag from the income tax, deemed inconsistent with the CC law on income 


\section{(4) Legislation Enacted}

It would hardly be practical to summarize here the innumerable laws enacted by the Minister Presidents during the period when they exercised the legislative function by decree. History confronted them and their associates with the staggering assignment of getting their broken-down state machinery back into some semblance of working order. No objective observer can deny these men his respect for a mission performed under exceptionally difficult conditions, spiritual no less than physical. They had to cope with the misery of defeat and the burden of foreign occupation; to erect a rudimentary framework of state organization; to fashion an emergency roof over the collapsed house into which their people-along with the masses of evacuees and expellees - had to be crowded. No rational plan of legislative reconstruction existed or could be followed. Emergency conditions and the requests of the occupation power dictated priority and urgency.

This section will, then, be confined to an endeavor to touch on some of the high points, the survey being largely confined to legislation of the pre-constitutional period.

Political Structure. Certainly the most significant action undertaken was the comprehensive pattern of legislation by which the politicaladministrative machinery of the Länder was reconstructed and their status as self-governing political entities restored. Guided by special AMG instructions, Land authorities developed legislation providing for elections ${ }^{103}$ in and organization ${ }^{103}$ of the townships (Gemeinde), organization of the county (Landkreis) structure ${ }^{105}$ and election of their representative bodies and officials. ${ }^{100}$ The boot-strap process culminated in the drafting, by elected conventions, ${ }^{107}$ of constitutions under which, after popular ratification, the Länder attained statehood and self-government.

taxation; a Bavarian law on consumer cooperatives enacted in disregard of objections previously raised by OMGUS; a law of Württemberg-Baden on the establishment of a constitutional court, found inconsistent with the standards set by AMG for such institutions; and a law of Hesse concerning trustees for blocked property which the Lond MIG Office in Wiesbaden had suspended pending examination by the Finance Division of OMGUS. Perhaps the most controversial issue was the Bavarian school law which, because of its undemocratic character, was vetoed twice by AMG.

103. Bavaria, Law of Dec. 18, 1945, [1946] GVB1. 230; Württemberg-Baden, Law of Jan. 10, 1946, [1946] RegB1. 35; Greater Hesse, Law of Dec. 15, 1945, [1946] GVB1. 7.

104. Bavaria, Law No. 31 of Dec. 18, 1945, [1946] GVB1. 225; Württemberg-Baden, [1946] RegB1. 55 ; Greater Hesse, Law of Dec. 21, 1945, [1946] GVB1. 1.

105. Bavaria, Law No. 32 of Feb. 18, 1946, [1946] GVB1. 229; Württemberg-Baden, Law No. 33 of MTarch 7, 1946, [1946] RegB1. 45; Greater Hesse, Law of Jan. 24, 1946, [1946] BVB1. 101.

106. Bavaria, Law of Feb. 21, 1946, [1946] GVB1. 247; Württemberg-Baden, Ordinance No. 105 of March 7, 1946, [1946] RegB1. 51; Greater Hesse, Law of Mfarch 7, 1946, [1946] GVB1. 73.

107. Bavaria, Law No. 36 of Feb 14, 1946, [1946] GVB1. 262; Election Law of 
Less reticence on the part of the Americans in giving the Germans guidance which they expected and desired after their long intellectual isolation might well have resulted in far better fundamental charters. ${ }^{108}$ A case in point is the re-introduction everywhere of proportional representation. The few American officials conversant with the fate of Weimar realized that the Hitler movement owed its rise to power largely to the accumulation of votes under the party-list system. Had Weimar had a system of majority elections, it is altogether probable that in all but a few constituencies the opposition parties would have combined to defeat the Nazis. ${ }^{109}$ AMG's failure to take affirmative action on this count may well have been a material disservice to a people not advanced beyond their democratic experience under Weimar and dominated by party dogmatism. ${ }^{110}$

Legal Reform. The new code of criminal procedure reverts, on the whole, to the situation that existed under Weimar. ${ }^{111}$ The opportunity was not overlooked, however, to incorporate improvements, particularly a number intended to strengthen substantially the rights accorded accused persons. By another reform the police authorities were deprived of their former power to mete out administrative penalties, the

Feb. 14, 1946, [1946] GVB1. 267; Law No. 45 of Oct. 3, 1946, [1946] GVB1. 309; Law of Oct. 18, 1946, [1946] GVB1. 315, as amended, [1946] GVB1. 325.

Greater Hesse, Law of May 16, 1946, [1946] GVB1. 139; Law of Oct. 14, 1946, [1946] GVB1. 177, as amended by Law of Oct. 30, 1946, [1946] GVB1. 188; the date for holding the plebiscite together with the election for the new Landtag was set by Law of Oct. 30, 1946, [1946] GVB1. 189.

Württemberg-Baden, Law No. 35 of March 21, 1946, [1946] RegB1. 159, and Ordinance No. 109 of June 6, 1946, [1946] RegB1. 175.

108. On the constitutions see Loewenstein, Political Reconstruction in Germany, Zonal aitd Interzonal, in Change and Crists in European Governament 41 et seq. (Pollock ed. 1947); for texts see Appendix, id. at 167 et seq.

109. This is convincingly demonstrated by Herarens, Democracy or Anarchy? 255 et seq. (1941).

110. At the present time a movement for the abolition of proportional representation is under way in Germany. Prominent among the opponents are the Berlin daily Der Tagesspiegel and two groups in Heidelberg which, after a straw poll held in November 1946, merged as the German Association of Voters to Combat Proportional Representation. In view of the fact that the system was inserted into the Constitutions (Bavaria, Art. 14; Hesse, Art. 75; Württemberg-Baden, Art. 52) and that constitutional amendment is difficult, the reform has little chances of success.

111. It was accomplished by a revision of the pre-Hitler code by an American text drawn up under SHAEF and thoroughly revised by the Legal Division in Berlin. The Strafrechtspflegeordming 1946 was published in Bavaria by Law of March 30, 1946, [1946] GVB1. 100 et seq.; Württemberg-Baden by Law No. 24, [1946] RegB1. 89 et scq.; Greater Hesse by Law of Feb. 21, 1946, [1946] GVB1. 13 et seq.; it entered into force in.Greater Hesse on March 1, 1946, in the two other Länder on April 1, 1946. Nest to an introductory law different in each Land, the legislation consists of two parts, namely (a) the Strafgerichtsverfassingsgesetz, a Land adjustment of the Judicature Act of 1877 (Gerichtsverfassungsgesetz) to CC and AMG legislation in matters of criminal justice, and (b) the Code of Criminal Procedure (Strafprozessordining 1946); the text 
cases being assigned to ordinary courts. ${ }^{112}$ Dictated by the alarming increase of the crime incidence, emergency acts on criminal law and its administration were passed.113 Fittingly, to dignify the entering into effect of the new constitutions, amnesties were granted for minor criminal offenders where the punishable acts had been committed for reasons of urgent personal need or under the impact of the general confusion caused by the collapse. ${ }^{114}$

More specifically in the field of legal reconstruction, a number of measures were enacted to regularize legal life, ${ }^{115}$ among them the extension of legal periods and the statutes of limitation, ${ }^{\mathbf{1 1 0}}$ an interest moratorium on loans granted by mortgage banks, ${ }^{117}$ and regulation of official publications and notices. ${ }^{118}$ In some instances, the measures were co-

of the latter is uniform for the three Länder; however, subsequently the individual Länder began to amend it in line with local requirements and not always in coordination with each other; see, e.g., Greater Hesse, Iaw of July 3, 1946, [1946] GVB1. 171.

112. Even under Weimar certain types of minor infractions, primarily those sanctionable under police ordinances, were dealt with by the police. The Nazis extended and abused the practice. For texts of the new measures see Bavaria, Law No. 12 of Jan. 28, 1946, [1946] GVB1. 54, and Law No. 57 of Nov. 30, 1946, [1947] GVB1. 16; Württemberg-Baden, Law of Nov. 26, 1945, [1946] RegB1. 1; Greater Hesse, Law of XSay 16, 1946, [1946] GVB1. 164; Wurttemberg-Baden also transferred the right to issue ordinances from the police to the administrative authorities. Isw of Feb. 7, 1946, [1946] RegB1. 40.

113. Bavaria introduced the new offense of jail-brealing by $\mathrm{Law}$ No. 55 of Oet. 28 , 1946, [1947] GVB1. 11; previously, recaptured prisoners had been subject to disciplinary measures of the prison authorities only.

Württemberg-Baden, by Law of Nov. 20, 1945, [1946] RegB1. 2, added to the criminal code a considerable number of acts punishable under existing conditions such as spreading alarming rumors. Law of April 4, 1946, [1946] RegB1. 19, introduced summary proceedings for certain offenses; Ordinance No. 115 of Mfay 10, 1946, [1946] RegB1. 166, temporarily (to the end of 1947) excused the public prosecutor from participation in the trial of offenses punishable by a maximum of two years in prison.

The same measure was adopted by Greater Hesse by Ordinance of $\mathrm{Mray} 23,1946$, [1946] GVB1. 164. Greater Hesse was more active in this field than the other Landcr. Ordinance of Jan. 7, 1946, [1946] GVB1. 91, credited a convicted person with the time he had served otherwise in any form of imprisonment (including concentration camp); Ordinances of April 4, 1946, [1946] GVB1. 99 and MFay 21, 1946, [1946] GVB1. 162 parmitted summary proceedings for certain criminal cases. Ordinance of $\mathrm{May}_{\mathrm{y}} 16,1946$, [1946] GVB1. 118 exempted minor convictions from entry in the criminal register.

114. For Württemberg-Baden, see [1947] RegB1. 39; [1947] SJZ 349; for Hesse, see [1947] GVB1. 36; [1947] SJZ 450; in both cases the laws were enacted by the Lardiag.

115. Enactments agreed on by the Länderrat and those passed under AMG instruetions are not included here.

116. Bavaria, Laws No. 27 of June 18, 1946, [1946] GVB1. 213, No. 30 of Aug. 22, 1946, [1946] GVB1. 221 and No. 58 of Jan. 17, 1947, [1947] GVB1. 16; WürttembergBaden, Laws of May 16, 1946, [1946] RegB1. 209 and April 23, 1947, [1947] RegB1. 3S; Greater Hesse, Ordinance of Jan. 17, 1946, [1946] GVB1. 55.

117. Württemberg-Baden, Ordinance of Mray 16, 1946, [1946] RegB1. 216.

118. Bavaria, Law No. 40 of Aus. 22, 1946, [1946] GVB1. 295; Greater Hesse, Ordinances of Oct. 24, 1945, [1945]GVB1. 1 and Oct. 10, 1946, [1946] GVB1. 226. 
ordinated by understandings among the Länder; the great diversification existing where this was not done does not make for legal security.

Civil Service. Resulting from policy instructions issued by AMG and subsequent close German-American cooperation, new civil service laws were enacted in the early period. The basic points of reform were improvement of the statutory rights of public officials and state employees and elimination of patronage by strict enforcement of the Weimar merit system. To this end, a number of American ideas on examinations for appointment and promotion and the establishment of lists of qualified candidates were grafted on the German system. ${ }^{119}$ Perhaps also appropriate to be included under this heading are the efforts, more administrative than legislative, of finding suitable personnel for the recreated state services-no easy task in view of the wide swath initially cut by the denazification process.

Denazification. Here, by far the greatest amount of legislative activity was devoted to implementation of the Länderrat-sponsored Law on Liberation from National Socialism and Militarism of March 5, 1946 which required an extraordinary number of executory and interpretative acts. ${ }^{120}$ Otherwise, the legislative effort in this field has been unimpressive. The Nazi sterilization law ${ }^{\mathbf{1 2 1}}$ was eliminated, as was the former regime's ban on kosher slaughtering. ${ }^{122}$ On the constructive side, a special fund was created for the indemnification of victims of persecu-

119. Greater Hesse, Law of Nov. 12, 1946, [1946] GVB1. 205; Bavaria, Law of Oct. 28, 1946, [1946] GVB1. 350.

120. For example, in Greater Hesse during the first year no fewer than twenty execttory ordinances of the Liberation Law were passed. The discrepancies among the Länder in procedure and treatment of former Nazis are so wide that the Ländcrrat has tried coordination and equalization, as yet without success; see [1946] SJZ 242.

121. Law of July 13, 1933, [1933] RGB1. I, 529, (in the version of Law of June 26, 1935, [1935] RGB1. I, 773) and Law of Feb. 4, 1936, [1936] RGB1. I, 119. Disagrcement existed among the Four Powers (and likewise within the American and British staffs) as to whether the Legislation should be repealed because, aside from obhoxious Nazi provisions, it served valuable eugenic purposes. The Länder filled the gap. Bavaria, by Law No. 4 of Nov. 20, 1945, [1946] GVB1. 1, repealed outright at the earliest possible date the entire legislation, quashed pending proceedings and strictly prohibited any further enforcement of measures formerly decreed under the law. Greater Hesse, by Ordinance of May 16, 1947, [1946] GVB1. 117 more cautiously suspended application "for the time being." Württemberg-Baden, by Law No. 34 of July 24, 1946, [1946] $\operatorname{RegB1} .207$, did likewise, exempting, however, $\S 14, \pi 2$, permitting interruption of pregnancy by a licensed doctor in case the life of the pregnant woman is in danger.

Abortions have become a major social problem in Germany. In 1947 the City Government of Berlin petitioned the Control Council for legislation which for the time being would suspend prosecutions for abortion under Section 218 of the Criminal Code. The quadripartite committee on the reform of the criminal code demurred, disagreeing on whether legislation on the subject was suitable for the CC or for the German authorities.

122. Only Greater Hesse repealed the Reich Law of April 21, 1933, [1933] RGB1. I, 203, by Law of Aug. 7, 1946, [1946] GVB1. 173. Repeal of a similar measure in Bavaria was disallowed by AMG because it had been enacted under the Republic. 
tion. ${ }^{123}$ Bavaria distinguished herself by a law directed against "racial folly" and "international hatred" 124 and by invalidating titles, decorations and similar distinctions invented by the Nazi regime. ${ }^{125}$

Emergency Measures. Under this heading, a plethora of legislation may be filed, including laws on housing, building, building materials, landlord-tenant relations, refugees, labor, employment, youth activities, health, rationing, distributing and marketing of all commodities, combatting the black market, finance, taxation and social insurance. But in all fields, straining the capacity of the ministerial bureaucracy to the utmost, was the necessity for translating quadripartite and zonal acts into Land legislation.

\section{(5) General Appraisal}

The political sociologist might be tempted to appraise Land legislation as a reflection of the general attitude of the Land governments toward democratic rehabilitation and of their zeal to obliterate the Nazi heritage. Measured by American confidence in the willingness of the new regimes to remove the Nazi rubble the results under the preconstitutional governments were certainly disappointing. Nor have the elected Landtage lived up to the expectation that once the democratic machinery went into operation legislative reconstruction and legal reform would be undertaken on a large scale. Quite possibly, in the initial period, they have been too busy implementing their constitutions and making their machinery run. At any rate, both Landlage and Minister Presidents have been almost exclusively concerned with attending to their immediate legislative exigencies, manifestly trusting that legislative reform would be undertaken and continued by quadripartite or zonal action or believing that in great measure the task must wait until a political organization for a united Germany comes into being. Perhaps still other extenuation may be found in the general belief that legal uniformity must be maintained and that Land legislation should not cut into the domain formerly regulated by Reich law. Whatever may be the reasons, the conclusion must be that while the Land governments have operated, under exceptionally difficult conditions, with reasonable efficiency as machines of state, they have not appreciably contributed to the occupation objective of denazifying German law.

123. Bavaria, Law No. 35 of Aug. 1, 1946, [1946] GVB1. 258; Greater Hesse, Law of July 7, 1946, [1946] GVB1. 226. The subject, at first regulated without coordination by legislation of the individual Land, was later taken over by the Länderrot where the original draft had to be rewritten at the request of AMIG; see [1947] SJZ 285, 407, 449. For the new version see Hesse, [1947] GVB1. 39.

124. Law No. 14 of March 13, 1946, [1946] GVB1. 134.

125. Law No. 17 of Miay 20, 1946, [1946] GVB1. 178. 


\section{(6) Bi-zonal Legislation}

Though in their second year of existence, the bi-zonal agencies created for joint control of economic life in the American and British zones have not sufficiently hit their stride to warrant discussion of their legislative activities here.

\section{CoNCLUSION}

The proliferation of the legislative process in present-day Germany, splintered into a multitude of uncoordinated agencies-quadripartite; Allied (zonal and bi-zonal); German (bi-zonal, zonal and Land)-has produced a situation approximating legislative chaos. Under this system of ill-defined responsibilities and overlapping jurisdictions, Ger' many is neither a confederation nor a federal state. This alarming state of affairs is largely the result of the original sin of Potsdam which, in the erroneous belief that decentralization equals democratization, dissolved an organic whole into its component elements. The trend towards disintegration can be halted only by a reversal of the decentralization policy which clearly has fallen by its own weight. Without the establishment of a common legislative agency for all Germany-and, if this is politically not feasible, at least for the three western zones-no Marshall plan can achieve economic recovery and promote political reconstruction. 